\title{
How to Make the Body Speak? Visual Disability, Verbalism and Embodied Speech
}

\author{
Virginia Kastrup \\ Universidade Federal do Rio de Janeiro, \\ RJ, Brasil.
}

\author{
Dannyelle Valente \\ University of Lumière Lyon 2, France and \\ University of Geneva, Switzerland
}

\begin{abstract}
Verbalism represents a controversial issue in the field of visual disability. It is frequently stated that blind people use statements with words and expressions which are not based on direct sensory experience. Sometimes it is considered a pathology or something specific to blind people. In taking the work of three blind researchers - Pierre Villey, Joana Belarmino and Bertrand Verine - as a guideline, this paper emphasizes two main points: 1) The usage of words with visual references constitutes a strategy of inclusion in a social environment dominated by vision; 2) The importance to develop new affirmative actions to stimulate embodied and multisensory discourse, favoring experiences of belonging and sharing between the blind and the sighted beyond the hegemony of vision.
\end{abstract}

Keywords: Visual Disability, Verbalism, Multisensory Experience, Embodied Speech.

\section{Como Fazer Falar o Corpo? Deficiência Visual, Verbalismo e Fala Encarnada}

Resumo: O verbalismo constitui um problema controverso no campo da Psicologia da deficiência visual. É frequente a afirmação de que pessoas cegas utilizam enunciados que portam palavras concretas, mas que não estão baseadas na experiência sensorial direta. Por vezes é considerado algo patológico e específico de pessoas que não dispõem da visão. Tomando como fio condutor o trabalho de três pesquisadores cegos - Pierre Villey, Joana Belarmino e Bertrand Verine -, o estudo destaca dois pontos principais: 1) O uso de palavras com referências visuais é uma estratégia desenvolvida pelas pessoas cegas visando sua inclusão num ambiente social dominado pela visão; 2) É importante desenvolver ações afirmativas de estímulo à produção discursiva encarnada e multissensorial, favorecendo experiências de pertencimento e partilha entre cegos e videntes, para além da hegemonia da visão.

Palavras-chave: Deficiência Visual, Verbalismo, Experiência Multissensorial, Fala Encarnada.

\section{¿Cómo Hacer que el Cuerpo Hable? Discapacidad Visual, Verbalismo y Discurso Incorporado}

Resumen: El verbalismo representa un tema controvertido en el campo de la discapacidad visual. Con frecuencia se afirma que las personas ciegas usan afirmaciones con palabras y expresiones que no se basan en la experiencia sensorial directa. A veces se considera una patología o algo específico de las personas ciegas. Al tomar el trabajo de tres investigadores ciegos - Pierre Villey, Joana Belarmino y Bertrand Verine - como una guía, este documento enfatiza dos puntos principales: 1) El uso de palabras con referencias visuales constituye una estrategia de inclusión en un entorno social dominado por la visión; 2) La importancia de desarrollar nuevas acciones afirmativas para estimular el discurso incorporado y multisensorial, favoreciendo las experiencias de pertenencia e intercambio entre los ciegos y los videntes más allá de la hegemonía de la visión.

Palabras clave: Discapacidad Visual, Verbalismo, Experiencia Multisensorial, Discurso Incorporado. 


\section{Introduction}

In the field of visual disability psychology, it is often stated that the language of the blind is marked by verbalism. The term refers to the utterance of statements containing words and expressions which are not based in direct sensory experience (Galiano, \& Baltenneck, 2007; Hatwell, Streri, \& Gentaz, 2003; Heller, \& Gentaz, 2014; Lewi-Dumont, 2011). A person with congenital blindness, who speaks about blue eyes or the white snow, is exercising verbalism. This term frequently takes on wide and imprecise outlines. For example, if a blind person states: "Brasília is a beautiful city”, sighted people may look with suspicion. Aren't they simply repeating something they heard from other people? Reacting with suspicion and doubt implies the idea that the experience of the beauty of the city, is the exclusive prerogative of visual perception. However, this assumption is being questioned. Verine (2013), a blind researcher in the field of linguistics, argues that it is strange that blind people often need to justify their enjoyment of trips, art and outdoor sports, as if those were activities which can only be enjoyed by vision, when the knowledge and enjoyment of the beauty of a city, a work of art and nature are also gained by tactile, auditory, olfactory and gustatory perception.

The originality of an aesthetic range that is focused on other senses is anchored in the cognitive body (Varela, Thompson, \& Rosch, 1993) of the blind person, mainly with its tactile platform, to know the world (Heller, \& Gentaz, 2014; Lederman, \& Klatzky, 1987). In the aforementioned case of the trip to Brasília, the multisensory cognitive body seems to be able to compose the experience of a beautiful city.

In the book La vie des aveugles, Henri (1948) quotes Maurice de La Sizeranne, founder of the Association Valentin-Haüy au service des aveugles et des malvoyants (France), to point out the aesthetic pleasures that even the sighted can enjoy through smell, hearing and touch, if they do not let themselves be absorbed by the visual aspects of the external world. He speaks about experiences that produce an emotional echo in the sighted, such as the crackle of the fire in a fireplace, the wind in the branches of the trees and the roar of the waves. He wonders why it wouldn't be the same to someone who does not need to close their eyes, a fortiori, to better hear "the poetry of a leaf that sings" or to sense "the smell of the pines". For a blind person, the house, the forest and the beach have, according to La Sizeranne, an "olfactory countenance" and an "auditory countenance" that conserve their emotional potency and confer to each landscape its own character (as cited in Henri, 1948, p. 45).

However, even if aesthetic pleasure is present through other sensory modalities, the life of a blind person certainly includes interactions with sighted people, conversations, the exchange of ideas, impressions and information. Studies indicate that language participates in the creation of hybrid mental images, integrating verbal information and perceptive traces (Cornoldi, \& Vecchi, 2000). In a previous study about the dreams of blind people (Kastrup, 2013; 2014), one of the interviewees, an early blind woman, recounted that she had dreamt about a white wedding dress. She gave a long description of the dress, with an emphasis on many tactile features: it was tight in the chest and then loosened up with pleats all around. The blouse was made of fine lace and had frills, and the sleeves were puffy and fastened at the arms. The dress was white, that is to say, the color was part of the image she described. At the end of the "debriefing interview" (Vermersch, 2000), after a slow and detailed investigation of the image in the dream, she concluded that she had said that it was white because everyone says that wedding dresses are most frequently white. Further ahead we will detail the method used in the debriefing interview, which permitted the modulation of a speech which at first possessed verbalist characteristics.

After an overview of the studies about verbalism and its place on the development of language in the blind, this article discusses the issues of verbalism from a social, political and cognitive perspective. Regarding the work of three blind researchers as a guideline, we suggest two main points of analysis: 1) verbalism as a strategy of belonging for blind people in a sighted linguistic community; and 2) The importance to develop new affirmative actions to stimulate embodied and multisensory discourse, favoring experiences of belonging and sharing between the blind and the sighted beyond the hegemony of vision.

\section{Verbalism and linguist development}

The studies about the linguistic behavior of the blind focus mainly on the field of language acquisition and development, and most of them are carried out with blind school-aged children. Few studies explore the issue of verbalism in adulthood.

In an interesting analysis of studies regarding the language of blind people, Galiano and Portalier (2009) 
point out the at times controversial positions of the scientific community regarding verbalism, which are explained by the greater or lesser importance attributed to language and direct experience in the development of knowledge. Cutsforth (1932; 1951), the author of the first study about verbalism in blind children, positioned himself clearly in favor of the supremacy of direct (visual) perceptive experience in language. In this case, the absence of vision leads to a flawed comprehension of the meaning of words. Cutsforth analyzed the attributes of objects enumerated by congenitally blind and late blind subjects. References to visually descriptive attributes were found in both groups, with a total of $48 \%$ in congenitally blind and $65 \%$ in late blind subjects. Based on this data, Cutsforth stated that verbalism was present in the lives of blind children, and he suggested that it was harmful to the cognitive development of these children, inasmuch as it weakened the connection between knowledge and perceived reality. Later on, in a study with blind, visually impaired and sighted children, Dunlea (1989) supported Cutsforth's thesis. For Dunhea, blind children possessed a limited capacity in their word usage and they had particular difficulties in generalizing words in different situations.

This negative view of verbalism was greatly mitigated by Peréz-Pereira and collaborators (Peréz-Pereira, \& Castro, 1997; Peréz-Pereira, \& Conti-Mansden, 1999), who considered that the construction of linguistic concepts did not only depend on perceived reality, since language itself was an instrument for the construction of knowledge. These researchers conducted a longitudinal study of a blind child and her sighted twin sister (observed from when they were 2 to 5 years old), and they analyzed many linguistic factors, such as the correct usage of pronouns or the use of imitations and repetitions. No important difference in language development was found between the two sisters.

In addition, Millar (1983) observed that even among sighted children, a large part of knowledge was acquired in the social environment through verbal language, without the participation of direct perception. In a similar way, Tetzchner and Martinsen (1980) found high rates of verbalism in both blind and sighted children. Other studies, based on the results of word association tests (Millar, 1983; Nolan, 1960) or the free creation of stories (Rosel et al., 2005) also showed that there were no differences between the linguistic capacities of the blind and the sighted.
Nowadays verbalism is still a problem that is pointed out by educators and parents of blind children. In an interview with a group of educators and physiotherapists in a specialized educational institute, Linders (2010, p. 21) lists the negative aspects related to verbalism that are frequently pointed out by these professionals, of which the main ones are the inappropriate usage of language, false or incomplete ideas and the fear of things which do not constitute real danger. On the other hand, as we have seen, many studies prove that language is a cognitive function which is developed without difficulties in blind children, allowing their participation in a full social life and access to instruction on every level, even the highest ones, and constitutes an important medium for the learning process.

\section{Verbal description of the sensorial experience}

Two recent studies by Chauvey and collaborators (Chauvey, Hatwell, \& Gentaz, 2013; Chauvey, Hatwell, Verine, Kaminski, \& Gentaz, 2012) indicated that the presence of verbalism was greatly reduced when the objects could be manually explored by both blind and sighted people. The researchers compared the verbal description given by congenitally blind, late blind and sighted subjects in two different tests: 1) the description of a person in their proximity and 2) the description of objects which were previously manipulated during the test. All three groups made use of a high rate of visual referents when they described people. However, when they described objects which were previously manipulated, tactile descriptive attributes prevailed in all three cases. The authors concluded that the participation and the weight of each sensory modality varied according to the cognitive resources involved in the situation. The experience of describing people called upon long-term memory, which includes representations constructed in a linguistic community dominated by vision, whereas the situation that involved tactile manipulation favored a short-term perceptive and cognitive treatment, which was predominantly tactile not only for the blind, but also for the sighted.

Moreover, other studies examining the language of the blind identified the use of multisensory references (mainly tactile and auditory) in the description of concepts and in the narration of mental images by these subjects (Anderson, \& Olson, 1981; Lambert 2003; Vinter, Fernandes, Orlandi, \& Morgan, 2013). These discoveries are linked with theories of embo- 
died cognition in the field of linguistics (Barsalou, 1999; Glenberg, \& Kaschak, 2002). According to this approach, the meaning of words does not originate in abstract and amodal symbolic relationships, but in bodily, perceptive and sensorimotor experiences.

Recent studies in this field suggest that there are multisensory specificities in the description of objects and concepts by the blind. Taking these results into consideration, we will follow with an analysis of the social and communicational network involved in blind people's usage of verbalism. We will also analyze the reasons why the multisensory and embodied production of discourse, which was identified in the studies mentioned above, still finds little space in the daily life of the blind, and in an intertextual context dominated by vision.

\section{Verbalism in the discourse of the blind: The mystery of vision, inclusion strategies and unilateral negotiations}

Pierre Villey (1914; 1927), a blind researcher of the beginning of the $20^{\text {th }}$ century and author of books about visual impairment (Le Monde des Aveugles, Laveugle dans le Monde des Voyants) states that the language of the sighted provides constant excitement to the intelligence and imagination. It introduces successive greater or lesser enigmas, which incite thought and invite blind people to overcome the limits of their understanding. In this sense, the language that carries visual images, brings constant cognitive challenges. The interaction with the sighted spurs learning and the imagination, kindling the desire to go beyond what they know. Villey warns us, however, that there is a risk that the blind person, due to hurry or impatience, does not make an imaginative effort and is led to mechanically repeating words which they understand, but which do not correspond to any concrete sensorial image. This doesn't mean that Villey denies the existence of verbalism. What it does is problematizing its mandatory character, which only stresses a unilateral movement of integrating the blind into a sighted society.

In the same way, Belarmino (2009) states that vision is an immense mystery to the congenitally blind. She asks:

Isn't it curious that what impresses us most, fascinates us most, what incites us most are the things, the phenomena that we cannot see? Phenomena, things, theories which seem to be surrounded by a region of mystery, an interval of non-communication, a shadow zone (p. 181).

Furthermore:

The world challenges us with the mystery, the interval between the known and the unknown, shadow zone where there always remains a residue to be communicated, interpreted, explained. It remains a place of "non-seeing" which encourages and drives our experience of knowing, understanding, interpreting, touching (p. 181).

For Belarmino (2009), the mystery of vision follows the life of the congenitally blind. However, the cognitive flux follows its path based on the other senses. Tangible objects induce a movement of touching and even the effort of understanding the world. In turn, the intangible, untouchable, non-perceptible to touch, such as clouds and stars, and scenes like "the magical meeting of the ocean with the line of the horizon" and "the sunset painted the sky bright red" (p. 183) are completely inaccessible. They generate "an experience of a hunger of seeing, an exercise for the brain to interpret, to create something, something which can be put in place of this absence of real images" (p. 184). She states that since she was very young she sought nourishment in this hunger of seeing in literature, and that now she touches the intangible through Braille.

Belarmino (2004) proposes the concept of a tactile worldview to deal with a mode of being in the world where the cognitive platform is predominantly tactile. She notes that all children, regardless of their visual condition, have a tactile speech, in the sense that their speech touches the objects. It is a close speech, structured from detail, touch and kinesthesia, but it is progressively inhibited, repressed, and in its place arises distanced visual speech. Tactile speech is conserved in poetic language, which does not seek to explain, argue or interpret, but only to touch.

We can say that there is an inevitable distance, which could be impossible to bridge, between the mode of perceiving and being in the world of people who live with or without vision. The visual mode attains the status of mystery for the congenitally blind, while sighted people see in the blind an enigma, someone strange. Therefore, strategies are developed on both sides in the face of this enigma and otherness, among which we can find verbalism.

Verine strongly problematizes the concept of verbalism and proposes raising the issue on new bases. 
In accordance with Dubois (2009), Verine (2007; 2009; 2014) states that in order to analyze the relationship between perceiving and saying, we cannot take language only in its referential function, that is, as a mode of describing the properties of objects. The issue should be expressed as an issue of the unfolding of perceptive experience in language. In Western culture, discursive practices and specific knowledge construct different relationships with the world. Philosophical, medical, educational, psychological, moral, philanthropic, legal, media and aesthetic discourses participate in this complex web of relationships between the speakers ${ }^{1}$.

Actors negotiate lexicons and discourses. These negotiations, which are not without tensions, compete for the development of knowledge and their position as speakers in the world. In this perspective, verbalism among the blind should be understood as a strategy and an attempt of negotiation with the sighted in the interdiscursive relations. As an inclusion strategy, verbalism still possesses a low negotiation coefficient, since the blind execute a unilateral movement to integrate themselves into the conversation with sighted people.

It is remarkable that the blind and the sighted create strategies to adjust their relationship. For example, it isn't uncommon to observe embarrassment and even discomfort in some sighted people when they are confronted with a blind person. One of the reasons for this is that the conversation is conducted with a very peculiar semiotics of faciality. We are used to basing our relationships on the gaze on "looking eye to eye", and some sighted people feel noticeably uncomfortable in talking without being seen by the person with whom they are speaking. On one hand, recent studies show that the blind and the sighted produce similar facial expressions in spontaneous situations that involve emotions such as fear, happiness or sadness (see, e.g., Valente, Theurel, \& Gentaz, 2017), yet on the other hand, we can observe a specific nature of the gaze and the movements of the eye and the head that are usually considered odd by the sighted. It is relatively common that, because of the absence of the gaze, congenitally blind people hold their head and eyes up or down. It is also common that blind people move their necks and ears, and not their eyes, in the direction of the speaker, to direct their attention to their hearing and to better follow the conversation. However, this can upset the sighted speaker, who usually interprets this gesture as a lack of attention. If the sighted speaker does not frequently interact with blind people, they don't notice that this is precisely an intentional gesture of attention.

In order to control and minimize discomfort in the sighted, it is not uncommon that the blinds are trained to direct their face and move their necks in order to simulate the gaze, thus giving the sighted the comfortable, though false experience of "looking eye to eye". These strategies are sometimes part of the set of techniques taught in rehabilitation courses for people with visual disability. In a similar way, discursive strategies are created to adjust their relationship with the sighted. Verbalism is one of them. However, it is important to emphasize the negative consequences brought on by this strategy, due to the fact that blind people need to bow down and meekly adapt themselves to a visuocentric world, which contributes to the invisibility of their way of knowing and being in the world. It is, as we said, a strategy with a low coefficient of negotiation, by being closer to a movement of unilateral adaptation to a world that remains visuocentric instead of an effective act of sharing that works towards the symmetric widening of all people's cognitive domains, and thus towards the creation of a common and heterogeneous world.

Verine (2013) directly denies the hypothesis of generalized and pathological verbalism and observes that in blind people's discourse, the tactile source of information is usually reduced to silence, even when it participates in multisensory perception. Sometimes tactile perception is subsumed in the description of the action that accompanies it and to which it contributes. For Verine, the verbalism hypothesis should make way for the hypothesis of self-censorship due to an actual cultural hierarchy of perceptive systems that is still present nowadays and which conditions the exclusion of the senses and the inhibition of non-visual speech. The lack of variety in the non-visual lexicon, compared to the visual lexicon, in terms of quantity and nuance, should be understood in this context.

\footnotetext{
${ }^{1}$ In Vivre sans voir: Les aveugles dans la société française, du Moyen Âge au siècle de Louis Braille Zina Weigand (2003) shows that interdiscursive relationships between the blind and the sighted cannot be understood without taking their historical development into consideration. The book shows how the history of blindness was written mostly by the sighted. In the field of disability studies, Martins $(2006 ; 2013)$ points out that the narratives of people with visual impairment are narratives of resistance. Research in this domain should open up and listen, to allow the knowledge that is produced to generate a social transformation.
} 
Tactile speech is rare and abbreviated, in daily life as in literature. This is a consequence, however, of a historical devaluation of tactile perception as a way of knowing the world in Western culture. Such devaluation is incorporated in the discourse of people with visual disability, which is manifested in the presence of visual references and the absence of tactile, auditory, olfactory and gustatory references. This shows that the small space still allocated to non-visual discourse constitutes a paradox, since non-visual experiences positively define the cognitive functioning of the blind. Such a paradoxical character is duplicated when we realize that non-visual experiences are the common and most easily shared prerogative between people with visual disability and the sighted.

Verine analyses the written production of the blind with a critical perspective, pointing out that they themselves incorporate the supposed inferiority of non-visual senses in their discourses. In the spirit of the ideas proposed by Varela et al. (1993), we can say that the blind person's cognitive body was removed from the process of knowledge, thus making space for knowledge based on information, which creates a dissociation between mind and body. Consequently, it is fitting to reflect on concrete actions that can stimulate the utterance of embodied speech based on the multisensory experiences of the blind. Embodied speech opens up horizons in a two-fold movement: it not only allows us to value the concrete experiences of the blind, but it can also open up pathways to create new spaces of discursive negotiation between the blind and the sighted.

\section{How can we make the body speak? Proposals to reveal embodied speech in blind people's discourse}

Dire le non-visuel. The need to change such a situation and to stimulate the presence of non-visual elements in the discourse of people with different abilities and disabilities was proposed in the short story contest Dire le non visuel that took place in France in the context of the bicentenary celebrations of Louis Braille. This contest resulted in the book Lautre beauté du monde (Verine, 2009), and its material was analyzed in interdisciplinary studies published in Dire le non visuel (Verine, 2014). The contest asked participants to write fiction or nonfiction texts about non-visual experiences, or texts with descriptions of characters, objects and places effected through tactile, auditory, olfactory and gustatory perceptions. Both people with visual disability and those without participated in the contest, whose objective was to foster a dialogue between writers and readers with both cognitive conditions. As a member of the panel of judges, Havelange highlights that the Dire le non-visuel project possessed a subversive character, inasmuch as it revealed the pitfall of a culture which insists in thinking about the world only in visual terms. The result of the contest showed not only the multisensory possibilities and potency of language, but also its difficulties, deficiencies and historically constructed impasses (Havelange, 2014). Beyond being a literary and scientific project, it was also a political project in stimulating the expression of the non-visual, engaging the blind and the sighted in overcoming the limits of language and culture. The short stories were published to also engage the readers in this process, favoring the dissemination of a multisensory discourse.

Debriefing interview. Another way of expressing the non-visual is the practice of conducting debriefing interviews (Vermersch, 2000) in studies involving blind people (Kastrup, 2014). The interview takes a lived experience as a reference, and it seeks the description of the experience, rather than its interpretation. Usually the interviewee tends to adopt the position of abstract speech, with a predominance of opinions, information, judgements and commentaries, instead of the effective description of the experience, of the cognitive gestures and concrete actions. One of the objectives is to create a change in the interviewee's speech, guiding them to leave the position of abstract speech and enter the position of an embodied speech.

Abstract or formal speech is characterized by generalizations, and frequently uses words such as "always", "never", and "frequently", which recall rather a type of task or action, than a specific situation. It is the role of the interviewer to guide the person towards the lived experience, so that it can speak for itself. In the position of embodied speech, the interviewee remains present when the experience is recalled. In other words, the past situation is even more present than the current situation of the interview. According to Depraz, Varela and Vermersch (2003), with an act of suspension, attention is redirected from the external world, where it is usually directed, to the internal world. Redirecting the exterior to the interior is followed by a change in the attentional attitude of seeking to an attentional attitude of letting-go (lâcher prise). With this way of guiding which finds resonances in both the method of phenomenological reduction and Buddhist meditation practices, the experience speaks for itself, without the 
intentional control of the self. In this way, it can access the pre-reflective dimension of experience and action.

Embodied speech is not speech about the experience, since the observer does not perceive his subjective life in an external and distanced manner. It is neither based on transmitted information nor on theoretical knowledge or mental representations. It is a speech inside of experience. Embodied speech makes the present and situated body speak and involves an attention to itself, to the present and to the act of speech itself. Accessing the pre-reflective dimension through the cognitive process of the debriefing interview produces an experience of awareness of certain knowledge. The interviewee can thus say what he was not even aware of knowing. Knowledge built on these bases is embodied, incarnated and distinct from theoretical knowledge, which is based on mental representations related to transmitted information.

It is worth going back to the case of the early blind woman who recounted her dream about a white wedding dress. The debriefing interview tried to confirm if the white color was really a part of the image of the wedding dress. The action of description and the cognitive acts of suspension, redirection of attention, letting-go (lâcher prise) and awareness changed the narrative of this image. In the beginning, there was a seemingly total hybridity, yet a more detailed exploration revealed that there were two different layers: a tactile layer and a verbal one. The first, which spoke of the tight, pleated and lacy dress with puffy sleeves, seemed to her the most concrete. She thus concluded that she had said that the dream dress had been white because she knew, through the accounts of sighted people, that wedding dresses are usually white. The description of this dream attests that perceptive and linguistic components are mixed in experience and in discourse, without a desire to mislead or hide a singular mode of perception. On the other hand, it is possible to escape the verbalist trap and say the non-visual through a cognitive process.

To produce a mode of speech centered inside experience by using debriefing interviews was also proposed in the book Histoires de cecités / Histórias de cegueiras (Stories of blindness) (Kastrup, \& Pozzana, 2015; 2017). It contains 16 stories of blind people and tries to deconstruct the supposed identity of the blind, focusing on their singularity and multiplicity. The stories carry the richness of perception of the blind and those with visual impairment, emphasizing the capacity, ability and potency of living without seeing. The narratives are also about the difficulties encountered in the city and in the relationships with other people and with their own self. The stories are based in embodied speech and multisensory experience.

Story creation workshops. A third strategy to reveal capacity and abilities of the blind were story creation workshops, conducted with children by Dannyelle Valente, together with the tactile book publisher, in a partnership with children's book author Hervé Tullet. Unlike traditional children's books with a beginning, a middle and an end, Hervé Tullet's works encourage the child's invention and intervention through multisensory language and drawings, improvisations and artistic interferences. Some books turn into sculptures or encourage the little reader to create fantastical narratives. In workshops with blind and visually impaired children, Hervé Tullet's great classics, such as Un Livre, Le Jeu des Yeux Fermés, Blop! and Le Livre Avec un Trou, were revisited through multisensory games and supports which stimulate speech situated inside experience. Each child was encouraged to choose between different textures, materials, cords and papers to freely create their own characters and narratives. When it was time to improvise a story, a mediator interfered in the moments when it was necessary to foster continuity and fluidity in the discourse with comments such as "Oh, is that right?", "And then what happened?", “Tell me more.”

In one of the workshops, whose aim was to stimulate speech situated inside experience, children were encouraged to create a story with a character that went through a tactile route. The character was embodied through the children's index and middle fingers, which simulated walking legs, a concept found in many make-believe children's games. This singular process of creating stories had the objective of encouraging an embodied narrative that was constructed and improvised step-by-step by entering tactile mini-sceneries. The cognitive and perceptive body in action thus gained a more important role in the children's speech. An excerpt of the story created by A., a congenitally blind 8-year-old boy, illustrates one of the achieved results:

Mediator: A. show us [on the tactile support] ${ }^{2}$ where your story starts.

${ }^{2}$ In brackets we include the descriptions of A.'s tactile explorations and gestures that were closely linked to the creative process in this storytelling workshop 
A: It starts here, there was this here, a magical bridge [the child touched the tactile bridge on the support], there was this magical bridge and there were also people right beside this bridge [the child showed the mediator the characters created with pieces of Lego], and then these people started to fight.

Mediator: Oh, really? A fight?

A: That's right, and then there was a crocodile right beside the fifth figure, here [the child touched the figure], and then a person walks in the direction of the crocodile [the child imitated the character walking with two fingers] but she didn't know that it was a crocodile! [the child passes the character below a paper arch which represents the crocodile].

Mediator: Really? And what did she think it was, then?

A: She thought it was.... She thought it was... [the child touched the upper part of the arch with the left hand, while keeping the other hand/character below]... a wheel that was turning, yes... [the child returned to imitating the character walking below the paper arch] and when he arrived, the crocodile opened its mouth, Grrrrrr!! He came right in and Boom! He ate him! [the child kept the hand/character below the arch].

Mediator: Oh, it ate your main character?

A: Ah (laughter), but it ate him raw, and didn't chew!

Mediator: Ah, so he is inside the crocodile's belly?

A:Yes, but then he will ask for something: "get me out of here now, or I'll cut your belly! So it [the crocodile] says Grrrrr! Grrrr! It opened its mouth, it yawned, Brraaau! [the child removed the hand inside the arch in a sudden movement, which represented the character coming out of the crocodile's mouth].

Mediator: Ah, so the crocodile yawned and he could get out?

A: Yes! And then he walked [the child continued imitating the walk with their fingers] and entered the magic bridge [the child passed the character/ hand below the bridge while exploring the bridge with the other hand].

The story creation activity guided through a tactile path and through a character situated in the child's own body, increased the possibility of an embodied narrative with a more sensorial and motor experience. We clearly observed this in the various moments where A. narrates and indicates the path taken by the character with gestures: "a person walks in the direction of the crocodile", "He came right in and Boom", "And then he walked." We also observed the usage of many auditory clues and narrative improvisations created only after certain tactile explorations. For example, the moment in which A explores the curvy shape of the crocodile that he had built and only then, after this exploratory contact, he integrates the element of a "turning wheel" in their narrative.

Actions such as the short story contest, debriefing interviews in research contexts, and tactile story creation workshops with blind children are some possible strategies that try to increase the participation of people with visual disability in the game of discursive negotiations, opening up other possibilities of inclusion, belonging and sharing beyond the verbalist strategy.

\section{Conclusion}

In proposing a review of empirical studies and bringing an analysis of the controversies present around the concept of verbalism, this study suggests that its presence in blind people's discourse is connected to a certain historically constructed discursive network, including negotiations between the blind and the sighted marked by hierarchy and a focus on vision. It is not an individual or pathological phenomenon, nor is it exclusive to the blind. Verbalism expresses a certain cognitive policy, that is, a certain mode of knowledge constructed on a collective network, that is crossing through and being intersected by the relationship with people, with the world and with oneself. Verbalism involves the position of abstract speech, based on information and mental representations, which can be modified and transformed into a position of embodied speech through concrete practices. The position of embodied speech is based on direct experience and mobilizes not only the mental space, but also the cognitive and multisensory body. In the case of blind people, abandoning verbalist strategies in favor of multisensory discursive production affects their relationships with others and with themselves.

By taking language in its pragmatic dimension (Austin, 1970), speech is a practice and the act of speaking is capable of producing and transforming reality. The act of speaking possesses a performa- 
tive dimension that affects experience and is able to modulate and even create it. In a short story contest, in debriefing interviews and in tactile story creation workshops with blind children, what matters is not only knowing the content of the experience, which words convey through the transparency of recounting. Beyond the knowledge of the experience lived by the blind, making the body speak means accessing the procedural and genetic dimension of experience. It means accessing its enacted dimension, the plane of co-emergence of speech and the speaker (Varela et al., 1993; Tedesco, Sade, \& Caliman, 2014).

The predominance of the visual is still so strong today, that the production of non-visual imagery and speech are usually inhibited by vision. Verbalism is a strategy to establish relationships between blind and sighted people. However, such relationships are constructed on a background of inequality, and they possess a low coefficient of openness. In this context, it is necessary to propose more affirmative actions, which put the cognitive capacity, ability and efficiency of the blind into a discourse. It is still necessary to produce the desire to describe, narrate, and speak inside of the experience of blindness. It is only in this way that we can cultivate the exchange of experiences on new foundations, where difference arises as a desirable roughness, a welcome friction, an otherness that allows us to widen our perception of the world and ourselves. Oral and written discursive production, coming from inside the experience of blindness, thus arises as a warning and an antidote against every kind of naturalization of the visual world and the false superiority of the sighted. Lastly, it problematizes the misleading transparency of vision, opening up the coefficient of openness in the relationships between the blind and the sighted.

To conclude, it is worth mentioning the testimony of Villet (2015), a young blind writer:

The moment I became blind, words gained the strength to narrate a world that had become invisible. Why be surprised, after that, in my trust in the verb, this vector of the impossible? In the voice of those around me, in the pen of the great authors read by voluntary readers, in the thread of the lines of Braille, I am indebted to the great, the small words of others, the fact that I have seen a little. I speak of seeing a little, not of seeing. Even with all the credit I owe them, words cannot do everything. Even if they taught me that I was a man, and have moved me when they made me think of the splendor of visible beauty, words can never replace the retina. The other's words take the place of my eyes only in an approximate way; in the same way they cannot exactly share my perception of the world.

Here we observe that heard or read words affect the construction of an experience, which is presented by Villet, not without a certain paradox, as the experience of "seeing a little". Villet points out this nuance to emphasize that verbal experience occupies an important space in the construction and enrichment of his knowledge of the world, but it cannot be considered a substitute for the retina. He also emphasizes that there is always a distance between perception and words, which entails an insurmountable limit in sharing perceptive experiences. Words are not direct representations of perception - and this is true both for the blind and the sighted.

We believe that instead of being an obstacle, this distance is fruitful. The possibility of the blind and the sighted to open themselves up to share knowledge, ignorance, perplexities, learning, certainties, uncertainties, deficiencies and efficiencies arises as a two-way street, activating processes of mutual enrichment. The encounter with otherness - in others and in ourselves - arises as richness and a privilege. Just like the language of the seeing presents a challenge and stimulates learning and the imagination among the blind, we suggest that the sighted, in a reciprocal movement, be equally stimulated in the inventiveness of their cognition through the interaction and exchange of multisensory experience with the blind. In this way, overcoming the limits of verbalism presents a healthy challenge and a learning experience for all of us.

\section{References}

Anderson, D. W., \& Olson, M. R. (1981). Word meaning among blind children. Journal of Visual Impairment and Blindness, 75, 165-168.

Austin, J. L. (1970). Quand dire c'est faire. Paris: Seuil. 
Barsalou, L. W. (1999). Perceptual symbol systems. Behavioral \& Brain Sciences, 22(4), 577-609.

Belarmino, J. (2004). Aspectos comunicativos da percepção tátil: A escrita em relevo como mecanismo semiótico da cultura (Doctoral dissertation). Pontifícia Universidade Católica de São Paulo, São Paulo, SP, Brazil.

Belarmino, J. (2009). O que percebemos quando não vemos. Fractal: Revista de Psicologia, 21(1), 179-184. https:// doi.org/10.1590/S1984-02922009000100014

Chauvey, V., Hatwell, Y., \& Gentaz, E. (2013). Verbalisme, références aux modalités sensorielles non-visuelles et communication verbale entre adultes aveugles et voyants. MEI Handicap et Communication, 36, 155-166.

Chauvey, V., Hatwell, Y., Verine, B., Kaminski, G., \& Gentaz, E. (2012). Lexical references to sensory modalities in verbal descriptions of people and objects by congenitally blind, late blind and sighted adults. Plos One, 7(8), e44020. https:// doi.org/10.1371/journal.pone.0044020

Cornoldi, C., \& Vecchi, T. (2000). Mental imagery in blind people: The role of passive and active visuospatial processes. In M. Heller (Ed.), Touch, representation and blindness (pp. 143-181). Oxford: Oxford University Press.

Cutsforth, T. D. (1932). The unreality of words to the blind. Teachers Forum, 4, 86-89.

Cutsforth, T. D. (1951). The blind in school and society. New York, NY: American Foundation for the Blind.

Depraz, N., Varela, F, \& Vermersch, P. (2003). On becoming aware. Amsterdam: John Benjamin.

Dubois, D. (2009). Le sentir et le dire. Paris: L'Harmattan.

Dunlea, A. (1989). Vision and the emergence of meaning. Cambridge: Cambridge University Press.

Galiano, A. R., \& Baltenneck, N. (2007). Interactions verbales et déficience visuelle: Le rôle de la vision dans la communication. Revue Electronique de Psychologie Sociale, (1), 47-54.

Galiano,A. R., \&Portalier, S. (2009). Les fonctions dulangage chez la personne aveugle: Méta-analyse dela relation entre connaissance et langage. L'Année Psychologique, 109, 123-153. http://dx.doi.org/10.4074/S0003503309001055.

Glenberg, A., \& Karchak, M. (2002). Grounding language in action. Psychonomic Bulletin \& Review, 9(3), 558-565. https://doi.org/10.3758/BF03196313

Hatwell, Y., Streri, A., \& Gentaz, E. (2003). Touching for knowing: Cognitive psychology of haptic manual perception. Amsterdam: John Benjamins.

Havelange, C. (2014). D’une rive à l'autre: La mise en récit des stéréotypes de la cécité. In B. Verine (Ed.), Dire le non-visuel: Approches pluridisciplinaires des discours sur les perceptions autres que la vue (pp. 27-38). Liège: Presses Universitaires de Liège.

Heller, M., \& Gentaz, E. (2014). Psychology of touch and blindness. New York, NY: Psychology.

Henri, P. (1948). La vie des aveugles. Paris: PUF.

Kastrup, V. (2013). Será que cegos sonham? : O caso das imagens táteis distais. Psicologia em Estudo, 18(3), 431-440. https://dx.doi.org/10.1590/S1413-73722013000300005

Kastrup, V. (2014). Images mentales de personnes aveugles congénitales et précoces: Le cas des images tactiles distales. In B. Verine (Ed.), Dire le non-visuel : Approches pluridisciplinaires des discours sur les perceptions autres que la vue (pp. 165-179). Liège: Presses universitaires de Liège.

Kastrup, V., \& Pozzana, L. (2015). Histoires de cécités. Talant: Les Doigts Qui Rêvent.

Kastrup, V., \& Pozzana, L. (2017) Histórias de cegueiras. Curitiba, PR: CRV.

Lambert, S. (2003). Modèle du Mind's Hand: contribution anatomo-fonctionnelle et comportementale à l'étude du lien entre l'image mentale et la perception dans le handicap visuel (Unpublished doctoral dissertation). Université of Lyon/ University of Strarbourg, France.

Lederman, S., \& Klatzky, R. (1987). Hand movements: A window into haptic object recognition. Cognitive Psychology, 19(3), 349-368. https://doi.org/10.1016/0010-0285(87)90008-9

Lewi-Dumont, N. (2011). Langage. Voir [barré], 38-39, 174-183.

Linders, C. (2010). Le langage flottant et autres énigmes dans la compréhension des mots par les enfants aveugles. Talant: Les Doigts Qui Rêvent. 
Martins, B. S. (2006). E se eu fosse cego? Narrativas silenciadas da deficiência visual. Porto: Afrontamento.

Martins, B. S. (2013). Pesquisa acadêmica e deficiência visual: resistências situadas, saberes partilhados. Revista Benjamin Constant, 19, 55-66.

Millar, S. (1983). Language and active touch: Some aspects of reading and writing by blind children. In A. E. Mills (Ed.), Language acquisition in the blind child: normal and deficient (pp. 167-186). London: Croom Helm.

Nolan, C. (1960). On the unreality of words to the blind. The New Outlook for the Blind, 54, 100-102.

Perez-Pereira, M., \& Castro, J. (1997). Language acquisition and the compensation of visual deficit: New comparative data on a controversial topic. British Journal of Developmental Psychology, 15(4), 439-459. https://doi. org/10.1111/j.2044-835X.1997.tb00740.x

Pérez-Pereira, M., \& Conti-Ramsden, G. (1999). Language development and social interaction in blind children. New York, NY: Psychology.

Rosel R., Fermin, J., Miedes, A. C., Jiménez, P. J., \& Rodrigues, J. C. O. (2005). Verbalism in the narrative language of children who are blind and sighted. Journal of Visual Impairment and Blindness, 99(7), 413-425.

Tedesco, S., Sade, C., \& Caliman, L. (2014). A entrevista na pesquisa cartográfica: A experiência do dizer. In E. Passos, V. Kastrup, \& S. Tedesco (Eds.), Pistas do método da cartografia: a experiência da pesquisa e o plano comum (Vol. 2, pp. 92-127). Porto Alegre, RS: Sulina.

Tetzchner, S., \& Martinsen, H. (1980). A psycholinguistic study of the language of the blind: I. Verbalism. International Journal of Psycholinguistics, 19, 49-61.

Valente, D., Theurel, A., \& Gentaz, E. (2017). The role of visual experience in the production of emotional facial expressions by blind people: A review. Psychonomic Bulletin \& Review, 25(2), 483-497. https://doi.org/10.3758/ s13423-017-1338-0

Varela, F., Thompson, E., \& Rosch, E. (1993). L'inscription corporelle de l'esprit. Sciences cognitives et expérience humaine. Paris: Seuil.

Verine, B. (2007). À la recherche du point de vue aveugle. Voir Barré, 34-35, 99-115.

Verine, B. (2009). L'autre beauté du monde. Paris: La Balle Au Bond.

Verine, B. (2013). Não podemos ver, não devemos tocar: Quais as repercussões dessa máxima no discurso das pessoas cegas? Revista Benjamin Constant, 19, 6-19.

Verine, B. (2014). Dire le non-visuel. Approches pluridisciplinaires des discours sur les perceptions autres que la vue. Liège: Presses Universitaires de Liège.

Vermersch, P. (2000). L’entretien d'explicitation. Issy-les-Molineaux: ESF.

Villet, R. (2015, Novembre 1). Romain Villet: Histoire de ma vue. Retrieved from http://romain-villet.blogspot.com. br/2015/10/en-passant-i.html

Villey, P. (1914). Le monde des aveugles, essai de psychologie. Paris: Flammarion.

Villey, P. (1927). L’aveugle dans le monde des voyants, essai de sociologie. Paris: Flammarion.

Vinter, A., Fernandes, V., Orlandi, O., \& Morgan, P. (2013). Verbal definitions of familiar objects in blind children reflect their peculiar perceptual experience. Child Care Health and Development, 39(6), 856-863. https://doi. org/10.1111/cch.12002

Weygand, Z. (2003). Vivre sans voir : Les aveugles dans la société française, du Moyen Âge au siècle de Louis Braille. Paris: Créaphis.

\section{Virginia Kastrup}

Graduação em Psicologia pela Universidade Federal do Rio de Janeiro (UFRJ), Rio de Janeiro - RJ. Brasil. Mestre em Psicologia pela UFRJ e doutora em Psicologia Clínica pela Pontifícia Universidade Católica de São Paulo (PUC-SP), São Paulo - SP. Brasil. Pós-doutora no CNRS/França (2002) e CNAM/França (2010). Atualmente é Professora Titular da Universidade Federal do Rio de Janeiro.

E-mail: virginia.kastrup@gmail.com 


\section{Dannyelle Valente}

Graduação em Artes pela Universidade do Estado de Santa Catarina (UDESC) - Brasil. Mestre e doutora em Estudos Culturais pela Université Paris 1 Panthéon-Sorbonne - França. Pós-doutora em Psicologia pela Université de Genève - Suiça. Atualmente professora em Psicologia da Université Lumière Lyon 2 - equipe de pesquisa Développement, Individu, Processus, Handicap et Education (DIPHE) et perquisadora associada ao departamente de psicologia da Université de Genève.

E-mail: dannyellevalente@gmail.com

Endereço para envio de correspondência:

Rua General Cristóvão Barcelos 280, ap. 603. Laranjeiras, Rio de Janeiro. CEP: 22245-110.

Recebido:27/06/2018

Aprovado: 03/07/2018

Received:27/06/2018

Approved: 03/07/2018

Recibido: 27/06/2018

Aceptado: 03/07/2018

How to cite: Kastrup, V., \& Valente, D. (2018). How to make the body speak? Visual disability, verbalism and embodied speech. Psicologia: Ciência e Profissão, 38(3), 572-583. https:// doi.org/10.1590/1982-3703000052018

Como citar: Kastrup, V., \& Valente, D. (2018). Como Fazer Falar o Corpo? Deficiência Visual, Verbalismo e Fala Encarnada. Psicologia: Ciência e Profissão, 38(3), 572-583. https://doi.org/10.1590/1982-3703000052018

Cómo citar: Kastrup, V., \& Valente, D. (2018). ¿Cómo hacer que el cuerpo hable? Discapacidad visual, verbalismo y discurso incorporado. Psicologia: Ciência e Profissão, 38(3), 572-583. https://doi.org/10.1590/1982-3703000052018 